\title{
Navike pušenja i stavovi učenika u Medicinskoj i Ekonomsko-turističkoj školi u Karlovcu
}

\section{Smoking habits and attitudes of students at the Medical and Economic and Tourism School in Karlovac}

\author{
Sabina Tomašić, Radoslav Kosić2,3 \\ ${ }^{1}$ Medicinska škola Karlovac, Dr. Andrije Štampara 5, 47000 Karlovac, Republika Hrvatska \\ ${ }^{1}$ Medical school Karlovac, Dr. Andrije Štampara 5, 47000 Karlovac, Croatia \\ ${ }^{2}$ Klinički Bolnički centar Rijeka, Klinika za pedijatriju, Istarska 43, 51000 Rijeka, Republika Hrvatska \\ ${ }^{2}$ University Hospital Center Rijeka, Clinic for pediatric, Istarska 43, 51000 Rijeka, Croatia \\ ${ }^{3}$ Fakultet zdravstvenih studija Rijeka, Sveučilište Rijeka, Viktora cara Emina 5, 51000 Rijeka, Republika Hrvatska \\ ${ }^{3}$ Faculty of Health Studies Rijeka, University of Rijeka, Viktora cara Emina 5, 51000 Rijeka, Croatia
}

\section{Sažetak}

Uvod: Pušenje je značajan javnozdravstveni problem, posebno u nerazvijenim i srednje razvijenim zemljama. Jedan je od najvažnijih uzroka obolijevanja. Ovisnost koja nastaje kod osoba koje redovito puše cigarete vrlo je jaka.

Cilj istraživanja: Utvrditi učestalost pušenja duhanskih proizvoda među učenicima srednje škole medicinskog i ekonomskog usmjerenja.

Ispitanici i metode: Ispitanici su učenici trećih i četvrtih razreda smjera medicinska sestra / medicinski tehničar iz Medicinske škole te smjera ekonomist iz Ekonomsko-turističke škole u Karlovcu. Korištena je anketa koja je izrađena za potrebe ovog rada. Za obradu podataka korištena je deskriptivna statistika i bivarijatna analiza.

Rezultati: Rezultati pokazuju da od ukupnog broja ispitanika, njih 39,29\% konzumira duhanske proizvode, što znači da je učestalost pušenja cigareta u uzorku visoka, tj. svaki treći učenik puši cigarete. Broj pušača među učenicima Medicinske škole veći je u odnosu na učenike Ekonomsko-turističke škole (41,11 $\%$ prema 37,18 \%). Ispitanici se uglavnom slažu da je pušenje štetno za njihovo zdravlje. Približno polovica $(41,7 \%)$ ispitanika ne zna zašto je počela pušiti cigarete, a 22,2 \% ih puši zbog stresa. Učenici Medicinske škole smatraju da pušenje nikako ne povećava radnu sposobnost i osobno zadovoljstvo te da pušenje uzrokuje rak pluća što pripisuju većem broju konzumiranih cigareta.

Zaključak: Budući da je iz istraživanja vidljivo da ispitanici koji su učenici dviju srednjih škola učestalo konzumiraju duhanske proizvode, potrebno je razmisliti o razvoju preventivnih programa koji bi mogli biti implementirani u razne školske i društvene sadržaje.

Ključne riječi: adolescenti, pušenje, učestalost, stavovi, navike

Kratki naslov: Adolescenti i pušenje

\begin{abstract}
Introduction: Smoking is a major public health problem, especially in underdeveloped and middle-developed countries. It is one of the most important causes of different diseases. The addiction that occurs with people who smoke cigarettes is very strong and many believe it is the strongest addiction.
\end{abstract}

Research goal: Research goal is to determine the frequency of smoking tobacco products among medical and economic high school students.

Participants and Methods: The respondents are students of third and fourth grades of the Medical School (nurse / medical technician) and the students of the Economics and Tourism School in Karlovac (economist). A survey was used that was designed for this paper. Descriptive statistics and bivariate analysis were used for data processing.

Results: A total of $39.29 \%$ of all respondents smoke, which means that the frequency of smoking in the sample is high, i. e. every third student smokes cigarettes. The number of smokers among the students of the Medical School is higher than the students of the School of Economics and Tourism (41.11\% vs. $37.18 \%$ ). Respondents mostly agree that smoking is harmful to their health. Approximately half (41.7\%) of respondents do not know why they started smoking and $22.2 \%$ of them smoke due to stress. Medical school students believe that smoking does not increase work ability and personal satisfaction, and that smoking causes lung cancer, which they attribute to the larger number of smoked cigarettes.

Conclusion: Given that the research shows that high school students frequently consume tobacco products, it is necessary to consider the development of prevention programs that could be implemented in various school and social facilities.

Keywords: adolescents, smoking, frequency, attitudes, habits

Running head: Adolescents and smoking 


\section{Uvod}

Pušenje duhanskih proizvoda doživjelo je nevjerojatan razvoj u posljednjih stotinu godina. Cigareta je najprodavaniji krajnji proizvod danas. Svake se godine proda gotovo 5500 milijardi cigareta širom svijeta, što je više od tisuću puta nego krajem prošlog stoljeća.

Izuzetna dostupnost duhana na tržištu može se pripisati propagandi duhanske industrije koja je duhan povezala s užitkom, romantikom i seksualnošću. Duhanska je industrija vrlo dobro razvijena, izuzetno je važan izvor prihoda u svakoj zemlji, pa je i zbog toga pušenje cigareta vrlo teško zaustaviti [1, 2].

Pušenje je jedan od najvažnijih uzroka različitih bolesti i prerane smrti te oštećuje gotovo svaki organ. Do sada su se podaci o upotrebi alkohola i drugih droga prikupljali $u$ okviru ESPAD istraživanja. Prvo istraživanje provedeno je 1995. godine u 26 zemalja, a posljednje 2015. godine. U gotovo svakoj zemlji ESPAD-a, od $50 \%$ do $80 \%$ srednjoškolaca pušilo je cigarete barem jednom u životu. Oni koji su pušili 40 i više puta nalaze se uglavnom u zemljama u kojima je cjeloživotna prevalencija pušenja također velika. U Austriji, Češkoj, Farskim otocima, Grenlandu, Njemačkoj, Litvi i Rusiji $40 \%$ ispitanih pušilo je 40 puta ili više tijekom svog života. Najniži postoci pronađeni su u Turskoj (13\%), na Malti (16\%), Islandu te u Portugalu (18\%). U 8 (uglavnom istočnih zemljalja) od 35 zemalja ESPAD-a dječaci su češće pušili cigarete nego djevojčice. Suprotno tome, više djevojčica nego dječaka na Grenlandu i otoku Man odgovorilo je da puši 40 puta ili više [3]. Od 2003. godine u Hrvatskoj se prvi put bilježi veći broj djevojaka koje su pušile cigarete barem jednom u životu u odnosu na mladiće. Čak $23 \%$ učenika u dobi od 15 do 16 godina u Hrvatskoj svakodnevno puši što je za $1 \%$ više od postotka u 1995. godini [3].

U istraživanju Šimetina i suradnika ukupno je 47,2 \% učenika pušilo bilo kakav oblik duhanskog proizvoda [4].

Utjecaj okoline i društva, slaba svijest o štetnosti pušenja, želja za individuacijom i pripadnošću grupi, demonstracija jednakosti, maltretiranje, protest protiv odraslih koji se snažno protive pušenju i mogućnost rješavanja „nevolje” koju mladi vide u cigaretama faktori su koji vode adolescente do prve cigarete. Pojava pušenja često je uzrokovana različitim isprepletenim razlozima, no adolescenti prvu cigaretu odabiru prvenstveno iz znatiželje. Vrlo je teško mladima objasniti zašto je pušenje štetno jer velik dio mladih obično ne sudjeluje u razgovorima o raku, kardiovaskularnim bolestima i drugim posljedicama koje su vidljive tek za desetak godina. Navedeno adolescentima nije blisko te ih ne odvraća od pušenja cigareta.

Pojava i učestalost pušenja među mladima općenito se povećavaju s godinama. Mladi koji počnu pušiti u ranoj dobi imaju veću vjerojatnost da će postati pušači i neće biti skloni prestanku pušenja kad odrastu. Dostupnost cigareta i drugih duhanskih proizvoda jedan je od važnih okolišnih čimbenika, vjerojatno povezan s početkom pušenja kod adolescenata.
Empirijski dokazi upućuju na negativnu povezanost između svjesnosti o štetnim učincima pušenja i brige za zdravlje s pušenjem adolescenata, ali i odraslih. Bolja svjesnost činjenice da je pušenje zdravstvena opasnost preventivni je čimbenik, ali u praksi ne mora nužno doprinijeti i prevenciji pušenja među mladima [5].

\section{Ciljevi}

Cilj je ovog istraživanja utvrditi učestalost pušenja duhanskih proizvoda među učenicima dviju srednjih škola medicinskog i ekonomskog usmjerenja.

Specifični ciljevi istraživanja sljedeći su:

- ispitati pušački status roditelja;

- ispitati u kojoj su dobi ispitanici počeli pušiti;

- ispitati razlog početka pušenja;

- ispitati razlike u stavovima o pušenju između učenika s obzirom na vrstu obrazovnog usmjerenja.

Hipoteze postavljene za ovo istraživanje sljedeće su:

- ne postoji razlika u učestalosti pušenja među učenicima Medicinske škole i učenicima Ekonomsko-turističke škole;

- postoji razlika u konzumaciji duhanskih proizvoda između učenika i učenica;

- učenici Medicinske škole i Ekonomsko-turističke škole razlikuju se s obzirom na stavove prema pušenju.

\section{Ispitanici i metode}

Ispitanici su učenici trećih i četvrtih razreda Medicinske škole smjera medicinska sestra / medicinski tehničar te učenici trećih i četvrtih razreda Ekonomsko-turističke škole smjera ekonomist, u dobi od 16 do 19 godina. $U$ istraživanju je sudjelovalo ukupno 168 učenika, 90 iz Medicinske škole i 78 učenika iz Ekonomsko-turističke škole. Dobivena je suglasnost ravnatelja obiju škola. Punoljetni učenici potpisali su suglasnost o dobrovoljnom sudjelovanju u istraživanju dok su za maloljetne učenike to učinili roditelji.

Anketa korištena u ovom istraživanju konstruirana je za potrebe ovog rada. Sastoji se od pitanja koja se odnose na sociodemografske podatke, pitanja o navikama pušenja te tvrdnjama o razlozima i stavovima prema pušenju. Ispitanici su odgovarali prema Likertovoj skali od 1 do 5 u kojoj 1 znači „U potpunosti se ne slažem", 2 "Uglavnom se ne slažem", 3 "Ne mogu se odlučiti", 4 "Uglavnom se slažem" i 5 "U potpunosti se slažem".

Korištena je deskriptivna statistika (frekvencije odgovora, aritmetičke sredine, standardna devijacija) i bivarijantna analiza (hi-kvadrat test). Hi-kvadrat testom ispitane su razlike u stavovima između učenika Medicinske škole i Ekonomsko-turističke škole u Karlovcu. Rezultati su se smatrali statistički značajnima na razini $p<0,05$. Statistička obrada podataka provedena je pomoću statističkog programa Statistica 13.5.0.17. (TIBCO Software Inc.). Podaci su prikazani tekstualno i tabelarno. 


\section{Rezultati}

$\mathrm{U}$ ispitivanju je sudjelovalo 168 ispitanika od kojih je 131 (78 \%) žena, a 37 (22 \%) muškaraca. Obuhvaćeno je njih 78 $(46,4 \%)$ iz Ekonomsko-turističke škole i 90 (53,6 \%) učenika iz Medicinske škole. Jednak je udio ispitanika u dobi od 17 $(46,4 \%)$ i $18(46,4 \%)$ godina, dok je najmanje ispitanika u skupini od $16(5,4 \%)$ i manje godina te 19 (1,8 \%) i više godina.

U Medicinskoj školi cigarete puši 37 učenika (41,1 \%), dok u Ekonomsko-turističkoj puši njih 29 (37,1 \%). Hi-kvadrat testom ispitana je razlika u učestalosti učenika pušača. lako više učenika puši u Medicinskoj školi, razlika nije statistički značajna na razini statističke značajnosti $p>0,05$.

Analizom podataka utvrđeno je da je značajno više roditelja nepušača čija su djeca, odnosno ispitanici, nepušači $p=$ $0,014, p<0,05$.

TABLica [1] Prikaz ispitanika po dobi

\begin{tabular}{lll}
\hline Godine & $\mathbf{N}$ & $\%$ \\
\hline 16 godina i manje & 9 & 5,4 \\
\hline 17 godina & 78 & 46,4 \\
\hline 18 godina & 78 & 46,4 \\
\hline 19 i više & 3 & 1,8 \\
\hline
\end{tabular}

TABLica [2] Raspodjela ispitanika na pušače $i$ nepušače po školama

\begin{tabular}{|c|c|c|c|c|}
\hline & $\begin{array}{c}\text { Medicinska } \\
\text { škola }\end{array}$ & $\begin{array}{c}\text { Ekonomska } \\
\text { škola }\end{array}$ & $\begin{array}{c}\text { Hi } \\
\text { kvadrat }\end{array}$ & $\mathbf{p}$ \\
\hline Pušači & $37(41,2 \%)$ & $29(37,18 \%)$ & \multirow{2}{*}{0,27} & \multirow{2}{*}{0,602} \\
\hline Nepušači & $53(58,8 \%)$ & $49(62,82 \%)$ & & \\
\hline
\end{tabular}

Tablica [3] Prikaz pušačkog statusa roditelja

\begin{tabular}{|c|c|c|c|c|c|c|}
\hline Roditelji & $\mathbf{N}$ & $\%$ & pušači & nepušači & $\begin{array}{c}\text { Hi- } \\
\text { kvadrat }\end{array}$ & $\mathbf{p}$ \\
\hline $\begin{array}{l}\text { Puše oba } \\
\text { roditelja }\end{array}$ & 37 & 22 & 17 & 20 & \multirow{4}{*}{10,53} & \multirow{4}{*}{0,014} \\
\hline $\begin{array}{l}\text { Puši samo } \\
\text { otac }\end{array}$ & 32 & 19 & 15 & 17 & & \\
\hline $\begin{array}{l}\text { Puši samo } \\
\text { majka }\end{array}$ & 26 & 15,5 & 15 & 11 & & \\
\hline $\begin{array}{l}\text { Ne puše } \\
\text { oba } \\
\text { roditelja }\end{array}$ & 73 & 43,5 & 19 & 54 & & \\
\hline
\end{tabular}

Iz Tablice 4 vidljivo je da su ispitanici u prosjeku počeli pušiti cigarete $u$ dobi od 15,2 godine.
TABLica [4] Prikaz prosječne dobi u kojoj su ispitanici počeli pušiti

\begin{tabular}{cccccc}
\hline & $\begin{array}{c}\text { Aritmetička } \\
\text { sredina }\end{array}$ & Mod & Min. & Maks. & $\begin{array}{c}\text { Standardna } \\
\text { devijacija }\end{array}$ \\
\hline Godine & 15,2 & 15 & 11 & 18 & 1,3 \\
\hline
\end{tabular}

Iz podataka navedenih u Tablici 5 vidljivo je da je većina ispitanika odgovorila da ne zna razlog početka pušenja, njih 30 (41,7\%). Ukupno 16 (22,2 \%) ispitanika počelo je pušiti zbog stresa, a 12 (16,7 \%) zbog društva. Osam učenika počelo je pušiti cigarete iz dosade ili usamljenosti, a samo jedan jer se time osjeća odraslijim.

TABLICA [5] Prikaz razloga početka pušenja

\begin{tabular}{lcc}
\hline & $\mathbf{N}$ & $\%$ \\
\hline Pušenjem se osjećam odraslijim & 1 & 1,3 \\
\hline Zbog društva & 12 & 16,7 \\
\hline Zbog stresa & 16 & 22,2 \\
\hline Zbog problema u obitelji, školi ili društvu & 3 & 4,2 \\
\hline Zbog dosade & 8 & 11,1 \\
\hline Zbog usamljenosti & 2 & 2,8 \\
\hline Ne znam & 30 & 41,7 \\
\hline
\end{tabular}

Hi-kvadrat testom ispitane su razlike u stavovima kod odgovora na tvrdnje između učenika Medicinske škole i Ekonomsko-turističke škole u Karlovcu. Podaci navedeni u Tablici 6 pokazuju da samo kod tvrdnje „Pušenje je opasno za moje zdravlje" postoji značajna razlika koja iznosi $p=0,001$, što ukazuje da je broj učenika Medicinske škole više svjestan štetnosti pušenja u odnosu na učenike Ekonomsko-turističke škole.

Podaci navedeni u Tablici 7 ukazuju na značajnost u odgovorima na tri pitanja iz ove kategorije. Naime, učenici Medicinske škole smatraju da pušenje nikako ne povećava radnu sposobnost i osobno zadovoljstvo, dok učenici Ekonomsko-turističke škole za istu tvrdnju ne mogu sa sigurnošću odlučiti slažu li se s njom ili ne $(p=0,020)$. Drugi je značajan pokazatelj u odgovoru ispitanika na tvrdnju da pušenje uzrokuje rak pluća $(p=0,001)$. Ovdje prevladaju odgovori učenika Medicinske škole koji se u potpunosti slažu s tvrdnjom, njih 39 (43,3 \%), dok 25 (32,0 \%) učenika Ekonomsko-turističke škole smatra da pušenje uzrokuje rak pluća. Naposljetku, kod pitanja o riziku raka pluća s većim brojem popušenih cigareta značajan je rezultat kod učenika Medicinske škole koji su više svjesni tog rizika od svojih kolega u Ekonomsko-turističkoj školi ( $p=0,011)$. Njih $59(65,5 \%)$ u potpunosti se slaže s navedenom tvrdnjom dok 31 (39,7\%) učenik Ekonomsko-turističke škole potvrđuje isto. 
Tablica [6] Prikaz ispitivanja stavova učenika između dviju srednjih škola

\begin{tabular}{|c|c|c|c|c|c|c|c|c|}
\hline Tvrdnja & Škola & $\begin{array}{c}1 \\
\text { "U potpunosti } \\
\text { se ne slažem" }\end{array}$ & $\begin{array}{c}2 \\
\text { "Uglavnom se } \\
\text { ne slažem" }\end{array}$ & $\begin{array}{c}3 \\
\text { "Ne mogu se } \\
\text { odlučiti" }\end{array}$ & $\begin{array}{c}4 \\
\text { „Uglavnom } \\
\text { se slažem“ }\end{array}$ & $\begin{array}{c}5 \\
\text { "U potpunosti } \\
\text { se slažem" }\end{array}$ & Ne znam & $\mathbf{p}$ \\
\hline \multirow{2}{*}{$\begin{array}{l}\text { Pušenje je } \\
\text { opasno za } \\
\text { moje zdravlje. }\end{array}$} & M & $0(0 \%)$ & $1(1,1 \%)$ & $2(2,2 \%)$ & $14(15,5 \%)$ & 73 (81,1\%) & 0 (0 \%) & \multirow{2}{*}{0,001} \\
\hline & $E$ & $5(6,4 \%)$ & $3(3,8 \%)$ & $3(3,8 \%)$ & $20(25,6 \%)$ & $45(57,7 \%)$ & $2(2,5 \%)$ & \\
\hline \multirow{2}{*}{$\begin{array}{l}\text { Pušenje je } \\
\text { popularno i } \\
\text { izgleda „cool“. }\end{array}$} & M & 45 (50 \%) & $26(28,8 \%)$ & $9(10 \%)$ & $5(5,5 \%)$ & $5(5,5 \%)$ & $0(0 \%)$ & \multirow{2}{*}{0,222} \\
\hline & $E$ & $48(61,5 \%)$ & $15(19,2 \%)$ & $5(6,4 \%)$ & $3(3,8 \%)$ & 4 (5,1%) & $3(3,8 \%)$ & \\
\hline \multirow{2}{*}{$\begin{array}{l}\text { Smeta mi } \\
\text { duhanski dim } \\
\text { kad drugi puše. }\end{array}$} & M & $17(18,8 \%)$ & 16 (17,7 \%) & 7 (7,7 \%) & $24(26,6 \%)$ & $23(25,5 \%)$ & $3(3,3 \%)$ & \multirow{2}{*}{0,849} \\
\hline & $E$ & $48(61,5 \%)$ & $15(19,2 \%)$ & $5(6,4 \%)$ & $3(3,8 \%)$ & $4(5,1 \%)$ & $3(3,8 \%)$ & \\
\hline \multirow{2}{*}{$\begin{array}{l}\text { Pušim i nemam } \\
\text { namjeru } \\
\text { prestati pušiti. }\end{array}$} & M & $42(46,6 \%)$ & $4(4,4 \%)$ & $11(12,2 \%)$ & $11(12,2 \%)$ & $5(5,5 \%)$ & 17 18,8 \%) & \multirow{2}{*}{0,096} \\
\hline & $E$ & $27(34,6 \%)$ & $4(5,1 \%)$ & $12(15,3 \%)$ & $3(3,8 \%)$ & $5(6,4 \%)$ & 27 (30 \%) & \\
\hline \multirow{2}{*}{$\begin{array}{l}\text { Pušim i } \\
\text { namjeravam } \\
\text { prestati pušiti. }\end{array}$} & M & $30(33,3 \%)$ & $9(10 \%)$ & $10(11,1 \%)$ & $5(5,5 \%)$ & 7 (7,7 \%) & $29(32,2 \%)$ & \multirow{2}{*}{0,883} \\
\hline & $E$ & $26(33,3 \%)$ & $5(6,4 \%)$ & $6(7,6 \%)$ & $6(7,6 \%)$ & $6(7,6 \%)$ & $29(37,1 \%)$ & \\
\hline \multirow{2}{*}{$\begin{array}{l}\text { Pokušao/la } \\
\text { sam prestati } \\
\text { pušiti, ali } \\
\text { neuspješno. }\end{array}$} & M & $46(51,1 \%)$ & $1(1,1 \%)$ & $3(3,3 \%)$ & $5(5,5 \%)$ & $6(6,6 \%)$ & $29(32,2 \%)$ & \multirow[b]{2}{*}{0,326} \\
\hline & $E$ & 33 (42,3 \%) & $6(7,6 \%)$ & $2(2,5 \%)$ & 7 (8,9 \%) & $5(6,4 \%)$ & $25(32,0 \%)$ & \\
\hline \multirow{2}{*}{$\begin{array}{l}\text { Maloljetnicima } \\
\text { su cigarete lako } \\
\text { dostupne. }\end{array}$} & M & $2(2,2 \%)$ & $0(0 \%)$ & $2(2,2 \%)$ & 25 (27,7 \%) & $60(66,6 \%)$ & $1(1,1 \%)$ & \multirow{2}{*}{0,113} \\
\hline & $E$ & 0 (0\%) & 1 (1,2 \%) & $5(6,4 \%)$ & 31 (39,7 \%) & 39 (50 \%) & $2(2,5 \%)$ & \\
\hline \multirow{2}{*}{$\begin{array}{l}\text { Ne odobravam } \\
\text { zabranu } \\
\text { pušenja na } \\
\text { području škole. }\end{array}$} & M & 25 (27,7 \%) & $12(13,3 \%)$ & $14(15,5 \%)$ & $8(8,8 \%)$ & $23(25,5 \%)$ & $8(8,8 \%)$ & \multirow[b]{2}{*}{0,350} \\
\hline & $E$ & $19(24,3 \%)$ & $4(5,1 \%)$ & $19(24,3 \%)$ & $8(10,2 \%)$ & $18(23,0 \%)$ & $10(12,8 \%)$ & \\
\hline \multirow{2}{*}{$\begin{array}{l}\text { U kafićíma } \\
\text { treba biti } \\
\text { dopušteno } \\
\text { pušiti. }\end{array}$} & $M$ & 7 (7,7 \%) & $12(13,3 \%)$ & $21(23,3 \%)$ & $21(23,3 \%)$ & $22(24,4 \%)$ & 7 (7,7 \%) & \multirow{2}{*}{0,260} \\
\hline & $E$ & $2(2,5 \%)$ & $6(7,6 \%)$ & $16(20,5 \%)$ & $16(20,5 \%)$ & $29(37,1 \%)$ & $9(11,5 \%)$ & \\
\hline \multirow{2}{*}{$\begin{array}{l}\text { Pušenje je } \\
\text { manji problem } \\
\text { u odnosu } \\
\text { na uporabu } \\
\text { droga. }\end{array}$} & M & $5(5,5 \%)$ & $5(5,5 \%)$ & $19(21,1 \%)$ & $22(24,4 \%)$ & 36 (40 \%) & $3(3,3 \%)$ & \multirow[b]{2}{*}{0,294} \\
\hline & $E$ & $4(5,1 \%)$ & $6(7,6 \%)$ & 7 (8,9 \%) & $25(32,1 \%)$ & 35 (44,8 \%) & $1(1,2 \%)$ & \\
\hline \multirow{2}{*}{$\begin{array}{l}\text { Namjeravam } \\
\text { pušiti kada } \\
\text { budem stariji. }\end{array}$} & M & $50(55,5 \%)$ & $2(2,2 \%)$ & 9 (10 \%) & 9 (10 \%) & $4(4,4 \%)$ & 16 & \multirow{2}{*}{0,338} \\
\hline & $E$ & $37(47,4 \%)$ & 7 (8,9 \%) & 7 (8,9 \%) & $5(6,4 \%)$ & $3(3,8 \%)$ & $(24,3 \%)$ & \\
\hline
\end{tabular}

Tablica [7] Prikaz razlike u stavovima učenika dviju škola

\begin{tabular}{|c|c|c|c|c|c|c|c|c|}
\hline & Škola & $\begin{array}{c}1 \\
\text { "U } \\
\text { potpunosti se } \\
\text { ne slažem" } \\
\end{array}$ & $\begin{array}{c}2 \\
\text { "Uglavnom se } \\
\text { ne slažem" }\end{array}$ & $\begin{array}{c}3 \\
\text { "Ne mogu se } \\
\text { odlučiti" }\end{array}$ & $\begin{array}{c}4 \\
\text { "Uglavnom se } \\
\text { slažem" }\end{array}$ & $\begin{array}{c}5 \\
\text { "U } \\
\begin{array}{c}\text { potpunosti se } \\
\text { slažem" }\end{array} \\
\end{array}$ & Ne znam & $\mathbf{p}$ \\
\hline \multirow{2}{*}{$\begin{array}{l}\text { Pušenje povećava } \\
\text { radnu sposobnost } \\
\text { i osobno } \\
\text { zadovoljstvo. }\end{array}$} & $M$ & $39(43,3 \%)$ & $17(18,8 \%)$ & $16(17,7 \%)$ & 9 (10\%) & 0 (0 \%) & 9 (10\%) & \multirow[b]{2}{*}{0,020} \\
\hline & $E$ & $24(30,7 \%)$ & $10(12,8 \%)$ & 17 (15,3 \%) & $4(5,1 \%)$ & $2(2,5 \%)$ & $21(26,9 \%)$ & \\
\hline \multirow{2}{*}{$\begin{array}{l}\text { Pušenje uzrokuje } \\
\text { slabovidnost, } \\
\text { spolnu nemoć i } \\
\text { neplodnost. }\end{array}$} & $M$ & $3(3,3 \%)$ & $8(8,8 \%)$ & $6(6,6 \%)$ & $32(35,5 \%)$ & $21(23,3 \%)$ & $20(22,2 \%)$ & \multirow[b]{2}{*}{0,092} \\
\hline & $E$ & $3(3,8 \%)$ & $6(7,6 \%)$ & 15 (19,2 \%) & $20(25,6 \%)$ & $11(14,1 \%)$ & $23(29,4 \%)$ & \\
\hline
\end{tabular}




\begin{tabular}{|c|c|c|c|c|c|c|c|c|}
\hline \multirow{2}{*}{$\begin{array}{l}\text { Pušenje uzrokuje } \\
\text { isušivanje kože } \\
\text { i prijevremeno } \\
\text { starenje. }\end{array}$} & $M$ & 0 (0\%) & $4(4,4 \%)$ & 7 (7,7 \%) & $29(32,2 \%)$ & $39(43,3 \%)$ & $11(12,2 \%)$ & \multirow[b]{2}{*}{0,227} \\
\hline & $\mathrm{E}$ & $4(5,1 \%)$ & $3(3,8 \%)$ & $8(10,2 \%)$ & 25 (32 \%) & 25 (32 \%) & 13 16,6 \%) & \\
\hline \multirow{2}{*}{$\begin{array}{l}\text { Pušenje uzrokuje rak } \\
\text { pluća. }\end{array}$} & $M$ & 1 (1,1 \%) & $2(2,2 \%)$ & $3(3,3 \%)$ & $24(26,6 \%)$ & $60(33,3 \%)$ & $0(0 \%)$ & \multirow{2}{*}{0,001} \\
\hline & $E$ & $4(5,1 \%)$ & $4(5,1 \%)$ & 7 (8,9 \%) & $16(20,5 \%)$ & $34(43,5 \%)$ & $13(16,6 \%)$ & \\
\hline \multirow{2}{*}{$\begin{array}{l}\text { Rizik od raka pluća } \\
\text { povećava se s } \\
\text { brojem popušenih } \\
\text { cigareta i ranim } \\
\text { početkom pušenja } \\
\text { duhana. }\end{array}$} & $M$ & $2(2,2 \%)$ & $3(3,3 \%)$ & $6(6,6 \%)$ & $17(18,8 \%)$ & $59(65,5 \%)$ & $3(3,3 \%)$ & \multirow[b]{2}{*}{0,011} \\
\hline & $E$ & $5(6,4 \%)$ & $3(3,8 \%)$ & $10(12,8 \%)$ & 18 (23\%) & $31(39,7 \%)$ & $11(14,1 \%)$ & \\
\hline \multirow{2}{*}{$\begin{array}{l}\text { Rizik od raka } \\
\text { pluća povećava } \\
\text { se ponovnim } \\
\text { paljenjem } \\
\text { polupopušene } \\
\text { cigarete i } \\
\text { uvlačenjem dima } \\
\text { iste cigarete } \\
\text { nekoliko puta. }\end{array}$} & M & $5(5,5 \%)$ & $2(2,2 \%)$ & 18 (20\%) & $11(12,2 \%)$ & $22(24,4 \%)$ & $32(35,5 \%)$ & \multirow[b]{2}{*}{0,631} \\
\hline & $E$ & $8(10,2 \%)$ & $3(3,8 \%)$ & $11(14,1 \%)$ & $6(7,2 \%)$ & $19(24,3 \%)$ & $31(34,4 \%)$ & \\
\hline \multirow{2}{*}{$\begin{array}{l}\text { Pušenje doprinosi } \\
\text { prijevremenom } \\
\text { umiranju. }\end{array}$} & M & $2(2,2 \%)$ & $6(6,6 \%)$ & $13(14,4 \%)$ & $24(26,6 \%)$ & 35 (38,8 \%) & $10(11,1 \%)$ & \multirow{2}{*}{0,134} \\
\hline & $E$ & $5(6,4 \%)$ & $9(11,5 \%)$ & $15(19,2 \%)$ & $19(24,3 \%)$ & $17(21,7 \%)$ & $13(16,6 \%)$ & \\
\hline \multirow{2}{*}{$\begin{array}{l}\text { Kod pušača duhana } \\
\text { postoji veća } \\
\text { mogućnost da će } \\
\text { koristiti i druge } \\
\text { droge. }\end{array}$} & $M$ & $16(17,7 \%)$ & $21(23,3 \%)$ & 18 (20\%) & $13(14,4 \%)$ & 7 (7,7 \%) & 15 (16,6 \%) & \multirow[b]{2}{*}{0,065} \\
\hline & $E$ & 25 (32 \%) & 7 (8,9 \%) & $11(14,1 \%)$ & $11(14,1 \%)$ & $6(7,6 \%)$ & 18 (23\%) & \\
\hline \multirow{2}{*}{$\begin{array}{l}\text { Ako prestanete } \\
\text { pušiti, pluća će se } \\
\text { vratiti u normalno } \\
\text { stanje za } 10 \text { godina. }\end{array}$} & $M$ & $3(3,3 \%)$ & 9 (10 \%) & $19(21,1 \%)$ & $21(23,3 \%)$ & $8(8,8 \%)$ & $30(33,3 \%)$ & \multirow[b]{2}{*}{0,061} \\
\hline & $E$ & 25 (32 \%) & $7(8,9 \%)$ & 11 (14,1 \%) & 11 (14,1 \%) & $6(7,6 \%)$ & 18 (23\%) & \\
\hline
\end{tabular}

\section{Rasprava}

Adolescencija u nekim slučajevima može biti jednostavan prijelaz iz djetinjstva u odraslu dob. Rizično ponašanje, konzumiranje i zlouporaba ovisničkih tvari poput cigareta, alkohola, lijekova i droga karakteristični su za osobe u pubertetu te postaju sve češći među adolescentima.

Istraživanje je provedeno u Medicinskoj školi i Ekonomskoturističkoj školi u Karlovcu. U istraživanju su sudjelovali učenici trećih i četvrtih razreda navedenih škola, njih ukupno 168. Uzorak većinom čine djevojke. Ukupno 70 (77,7 \%) učenica je iz Medicinske škole, a 61 (78,2 \%) iz Ekonomsko-turističke škole. Učenika je 20 (25,6 \%) iz Medicinske, a 17 (21,7 \%) iz Ekonomsko-turističke škole. Odnos broja učenica naspram učenika iznosi 3:1 u korist učenica, što je i očekivano s obzirom na to da se radi o obrazovnim smjerovima koje u većem broju odabiru djevojke.

Rezultati istraživanja pokazuju da je najveći broj pušača među učenicima četvrtih razreda u objema školama, njih 24 (26,6 \%) u Medicinskoj školi te 18 (23,0 \%) u Ekonomskoturističkoj školi. Učestalost pušenja kod učenika Medicinske škole veća je nego u Ekonomsko-turističkoj školi. Kod učenika trećih razreda broj je pušača osjetno niži, u Medicinskoj školi njih je 13 (14,4 \%) dok je u Ekonomsko-turističkoj školi njih 11 (14,1\%).
Istraživanje koje je proveo Sakoman sa suradnicima među učenicima u Hrvatskoj, prosječne dobi od 16,8 godina pokazuje da je 81,2 \% mladića i 78,8 \% djevojaka pušilo cigaretu jednom ili više puta. Polovica ispitanika (49,6 \%) pušila je u posljednjem mjesecu, a trećina njih (32,5 \%) pušila je svakodnevno [6]. Međutim, istraživanje provedeno u Zagrebačkoj županiji u trećim i četvrtim razredima srednjih škola na području četiri grada pokazalo je da je udio pušača veći među djevojkama nego među mladićima. Od ukupnog broja ispitanih, 47,3 \% djevojaka puši, a mladića $36 \%$. Također je utvrđeno da je broj pušača veći među učenicima koji pohađaju trogodišnji obrazovni program u odnosu na one koji pohađaju četverogodišnji. Sličan rezultat dobiven je istraživanjem među srednjoškolcima istog uzrasta u Primorsko-goranskoj županiji gdje je utvrđen veći udio djevojaka u odnosu na mladiće koji puše cigarete [7].

Rezultati provedenog istraživanja u dvjema srednjim školama u Karlovcu pokazuju da gotovo svaki drugi učenik Medicinske škole puši (41,1 \% pušača prema 58,9 \% nepušača) te svaki treći učenik Ekonomsko-turističke škole (37,2 \% pušača prema 62,8 \% nepušača). 
Istraživanje reprezentativnog uzorka zagrebačkih srednjoškolaca i učenika osmih razreda osnovnih škola pokazalo je da samo 22,1 \% mladića i 16,5 \% djevojaka u četvrtom razredu nije probalo nijedan duhanski proizvod. Posebno zabrinjava činjenica da su razlike među spolovima koje su postojale u korist mladića u prethodnim istraživanjima nestale ili se značajno smanjile. Duhanske proizvode dnevno konzumira od $30 \%$ do $40 \%$ učenika. U trećem i četvrtom razredu srednje škole postoji značajna razlika prema spolu. Ukupno 40 \% mladića i $30 \%$ djevojaka puši svakodnevno u trećem razredu srednje škole, dok $38 \%$ djevojaka puši u četvrtom razredu srednje škole, a mladića $29 \%$ [8].

Prema izvještaju o trendu pušenja istraživanje WHO-a pokazuje da je u Hrvatskoj 2000. godine pušilo 44,6 \% mladića u dobi od 15 do 24 godine i 34,7 \% djevojaka istih godina. Deset godina kasnije, među pušačima je bilo 43,5\% mladića i 39,2 \% djevojaka u dobi između 15 i 24 godine. Pretpostavlja se da će 2025. pušiti 43,4 \% mladića i 47,6 \% djevojaka. Najveća je učestalost pušenja među muškarcima u dobi od 25 do 39 godina i djevojkama u dobi od 15 do 24 godine [9].

Iz podataka WHO-a može se iščitati da je zastupljenost pušenja u društvu u razvijenim zemljama manja nego u zemljama u razvoju te u nerazvijenim zemljama. U razvijenim se zemljama bilježi stagnacija broja pušača ili blagi pad, dok u ostalim zemljama broj pušača raste [10]. Budući da se Hrvatska može smatrati zemljom u razvoju, i za nju vrijedi isto.

Uzevši u obzir da polaznici Medicinske škole imaju puno praktičnog rada koji se veže za nastavu, oni uglavnom ostaju u školi ili bolnici duže nego njihovi kolege drugih obrazovnih usmjerenja, što također može utjecati na njihovu učestalost pušenja u usporedbi s učenicima drugih usmjerenja. Tome u prilog govore i rezultati ankete među učenicima srednjih škola provedene u Zagrebu 1997. godine koja pokazuje da je aktivno bavljenje sportom, atletikom ili vježbanjem povezano sa stavovima i navikama pušenja, što ukazuje na činjenicu da pojedinac koji se više bavi sportskim aktivnostima manje puši, ima više negativnih stavova o pušenju te boravi u društvu u kojem je manji broj pušača [6].

\section{Zaključak}

Istraživanje je pokazalo da 39,29 \% ispitanika puši, što znači da je učestalost pušenja $u$ ispitivanom uzorku visoka, odnosno da svaki treći učenik srednje škole puši. Broj pušača među učenicima Medicinske škole veći je u četvrtom razredu (53,33 \%) u odnosu na treći razred (28,89\%).

Broj pušača među učenicima Medicinske škole veći je u odnosu na učenike Ekonomsko-turističke škole $(41,11 \%$ prema 37,18 \%). Ukupno 27,78 \% učenika Medicinske škole puši svakodnevno, dok svakodnevno 24,36 \% učenika Ekonomsko-turističke škole puši, a povremeno cigarete puši njih $16,67 \%$.

Jedna petina svih ispitanika ne slaže se sa zabranom pušenja u okruženju škole te se petina ispitanika slaže sa zabranom pušenja u okruženju škole. Trećina ispitanika ne zna ili se ne može odlučiti.

Kod odgovora na tvrdnju „Pušenje je opasno za moje zdravlje" postoji statistički značajna razlika. Navedeno ukazuje na to da su učenici Medicinske škole više svjesni štetnosti pušenja u odnosu na učenike Ekonomsko-turističke škole.

Razlike u stavovima o pušenju cigareta među učenicima dviju škola postoje. Učenici Medicinske škole smatraju da pušenje nikako ne povećava radnu sposobnost i osobno zadovoljstvo te da pušenje uzrokuje rak pluća što povezuju s većim brojem popušenih cigareta.

\section{Nema sukoba interesa}

\section{Authorsdeclare no conflictofinterest}

\section{Literatura}

[1] Čagalj M., Ivanković M. Temeljne značajke duhanske industrije u EU - s posebnim osvrtom na Republiku Hrvatsku, 2017. Dostupno na: https://bib.irb.hr/datoteka/896600.Temeljne_znaajke_duhanske_ industrije_u_EU_MC agalj.pdf; Pristupljeno: 3. 5. 2020.

[2] Elflein J. Global cigarette consumption from 1880 to 2017 (in billion cigarettes), 2019. Dostupno na: https://www.statista.com/statistics/279577/globalconsumption-of-cigarettes-since-1880/; Pristupljeno: 3. 5. 2020.

[3] Kuzman M, Pejnović F, Pavić Šimetin I, Pejak M. Europsko istraživanje o pušenju, alkoholu i drogama među učenicima (ESPAD). Hrvatski zavod za javno zdravstvo: Zagreb, 2016.

[4] Pavić Šimetin I, Mayer D, Milanović S. M, Franelić I. P, Jovičić D. Istraživanje o zdravstvenom ponašanju učenika, Health Behaviour in School-aged Children - HBSC 2013/2014, Osnovni pokazatelji zdravlja i dobrobiti učenika i učenica u Hrvatskoj. Hrvatski zavod za javno zdravstvo, Zagreb, 2016. Dostupno na: https://www.hzjz.hr/wp-content/uploads/2016/10/HR_ESPAD_2015_RGB_3.pdf; Pristupljeno: 3. 5. 2020.

[5] Truth Initiative Experimental Tobacco Marketing, 2018. Dostupno na: https://truthinitiative.org/sites/default/files/media/files/2019/03/ truth_initiativeexperiential_tobacco_marketing-fact_sheet-FINAL. pdf [02.12.2019.] Pristupljeno: 5. 5. 2020.

[6] Sakoman S, Kuzman M, Šakić V. Pušačke navike zagrebačkih srednjoškolaca. Društvena istraživanja. 1997; 6 (4-5): 513-35, ID:31661

[7] Malatestinić $Đ$, Roviš D, Mataija-Redžović A, Dabo J, Janković S. Prevalencija rizičnih ponašanja adolescenata, anketni upitnik. Medicina Fluminensis. 2008: 44 (1), 80-4, ID:25955

[8] Ljubotina G, Galić J. Obiteljski odnosi i konzumacija droga na populaciji adolescenata grada Zagreba. Ljetopis socijalnog rada. 2002; 9 (2), 207-32, ID:3521

[9] World Health Organisation. Cigarette smoking, 2018. Dostupno na: https://www.who.int/news-room/detail/19-12-2019-who-launchesnew-report-on-global-tobacco-use-trends. Pristupljeno: 5. 5. 2020.

[10] World Health Organisation. Tobacco Fact sheet №339 May 2014. Dostupno na: https://www.who.int/news-room/fact-sheets/detail/tobacco. Pristupljeno: 5. 5. 2020. 